\title{
Broadening the fear-avoidance model of chronic pain?
}

Citation for published version (APA):

Boselie, J. J. L. M., \& Vlaeyen, J. W. S. (2017). Broadening the fear-avoidance model of chronic pain? Scandinavian Journal of Pain, 17, 176-177. https://doi.org/10.1016/j.sjpain.2017.09.014

Document status and date:

Published: 01/10/2017

DOI:

10.1016/j.sjpain.2017.09.014

Document Version:

Publisher's PDF, also known as Version of record

Document license:

Taverne

Please check the document version of this publication:

- A submitted manuscript is the version of the article upon submission and before peer-review. There can be important differences between the submitted version and the official published version of record.

People interested in the research are advised to contact the author for the final version of the publication, or visit the DOI to the publisher's website.

- The final author version and the galley proof are versions of the publication after peer review.

- The final published version features the final layout of the paper including the volume, issue and page numbers.

Link to publication

\footnotetext{
General rights rights.

- You may freely distribute the URL identifying the publication in the public portal. please follow below link for the End User Agreement:

www.umlib.nl/taverne-license

Take down policy

If you believe that this document breaches copyright please contact us at:

repository@maastrichtuniversity.nl

providing details and we will investigate your claim.
}

Copyright and moral rights for the publications made accessible in the public portal are retained by the authors and/or other copyright owners and it is a condition of accessing publications that users recognise and abide by the legal requirements associated with these

- Users may download and print one copy of any publication from the public portal for the purpose of private study or research.

- You may not further distribute the material or use it for any profit-making activity or commercial gain

If the publication is distributed under the terms of Article $25 \mathrm{fa}$ of the Dutch Copyright Act, indicated by the "Taverne" license above, 
Editorial comment

\title{
Broadening the fear-avoidance model of chronic pain?
}

\author{
Jantine J.L.M. Boselie ${ }^{\mathrm{a}, *}$, Johan W.S. Vlaeyen ${ }^{\mathrm{a}, \mathrm{b}}$ \\ a Clinical Psychological Science, Maastricht University, The Netherlands \\ ${ }^{\mathrm{b}}$ Research Group Health Psychology, KU Leuven University, Belgium
}

\section{The "fear-avoidance model of chronic pain": what and why?}

In this issue of the Scandinavian Journal of Pain, Katherine Curtin and Deborah Norris [1] report on an online cross-sectional study in participants with self-reported chronic musculoskeletal pain (CMP). The study aimed to investigate the impact of ruminative anxiety and mindfulness on components of chronic pain (i.e., pain experience, pain catastrophizing, pain-related fear/avoidance) as proposed in the fear-avoidance model [2]. The fear-avoidance model presents a possible pathway by which injured individuals can get caught into a negative downward spiral, the so-called fearavoidance cycle, which fuels negative pain-related outcomes. In this vicious cycle, a catastrophic interpretation of pain might lead to pain-related fear, which in turn leads to defensive behaviours (i.e., avoidance and/or hypervigilance), resulting in disability and (more) pain. The authors hypothesise that a maladaptive cognition such as anxious rumination will be a risk factor for developing chronic pain. In contrast, a strategy that corrects this maladaptive cognition, such as mindfulness could be considered as a protective factor against maladjustment to pain. In other words, anxious rumination perpetuates the fear-avoidance cycle while mindfulness could prevent and/or break the fear-avoidance cycle.

\section{Anxious rumination and mindfulness needed in the "fear-avoidance model"?}

Anxious rumination was measured with the Perceived Stress Scale-10. Mindfulness, defined as cognitive behavioural strategy that promotes present-moment awareness in an intentional and non-judgmental manner, was measured with Five Facet Mindfulness Questionnaire-sf. In line with the author's expectations, results showed that ruminative anxiety was positively correlated with pain severity (i.e., pain experience), pain catastrophizing, pain-related fear/avoidance, and pain interference, but negatively

DOI of refers to article: http://dx.doi.org/10.1016/j.sjpain.2017.08.006.

* Corresponding author at: Maastricht University, Faculty of Psychology and Neuroscience, Clinical Psychological Science, Universiteitssingel 40, Postbus 616, 6200 MD Maastricht, The Netherlands.

E-mail address: jantine.boselie@maastrichtuniversity.nl (J.J.L.M. Boselie). correlated with mindfulness. Pain severity, pain catastrophizing, pain-related fear/avoidance, ruminative anxiety, and mindfulness significantly predicted $70.0 \%$ of the variance in pain interference, with pain severity, ruminative anxiety and mindfulness being unique predictors. These results may incite some doubts regarding the completeness of the fear-avoidance model. The authors propose that the fear-avoidance model should therefore be adjusted to include ruminative anxiety as a predisposing psychological vulnerability and mindfulness as an effective strategy that breaks the cycle of chronic pain.

\section{3. "Building what is strong" better than "fixing what is wrong"?}

Including both anxious rumination and mindfulness in the fearavoidance model is in line with the aim of positive psychology to have a more complete and balanced scientific understanding of the human experience, by abandoning the exclusive focus on vulnerability factors and 'fixing what is wrong' towards including protective factors and 'building what is strong' [3]. Examining both vulnerability and protective factors will help to disentangle what leads to outcomes of recovery, sustainability (perseverance in valued activities despite pain) and growth (benefit finding due to pain) [4]. In fact, the fear-avoidance model already specified besides the negative downward spiral, a positive upward spiral. When pain does not elicit fear, an injured individual will confront movements or activities associated with pain. This confrontation and engagement in daily activities will result in functional recovery. Originally, the model did not specify other factors, besides the absence of fear that may elicit this upward spiral to recovery. However, since its conception the model has evolved and expanded. Positive affect and optimism were for instance added as factors that fuel this upward spiral, as they may promote the pursuit of valued life goals, in contrast to a persistent attempt to control or to avoid pain $[5,6]$. Positive affect and optimism can also be regarded as protective factors that can reduce the intensity of fearavoidance cycle components, such as pain catastrophizing [4,7]. In a similar vein, not only individual characteristics may impact that fear-avoidance cycle, also the social context can be important. For example, the threat value of pain can be increased when health care providers unwittingly transfer their own pain-related fears to their patients [8]. 


\section{Including protective and vulnerability factors within the "fear-avoidance model"}

Seeing that there are far more factors to consider in the context of fear-avoidance, the proposed adjustment by Curtin and Norris is therefore maybe too restricted. We propose the inclusion of components that are far more broadly formulated, namely protective and vulnerability factors in contrast to mindfulness and ruminative anxiety, respectively. Moderating factors previously identified by the fear-avoidance model (e.g., negative affectivity and anxiety sensitivity) can then fall within the component vulnerability factors, just as ruminative anxiety (as identified in this study) or other overlapping constructs, such as stress. That is, this study measured ruminative anxiety by assessing perceived stress as it is a component of ruminative anxiety. But persistent stress itself can lead to maladaptive neurobiological changes in pain processing pathways, resulting in enhanced pain sensitivity (i.e., stress-induced hyperalgesia), which in turn can exacerbate the pain condition [9]. In other words, experiencing stress can also be identified as a vulnerability factor in this context, just as much as ruminative anxiety can. Having a more broadly stated component, that can include these different but related vulnerability and protective factors, will parsimoniously preserve the fear-avoidance model's simplicity while increasing its explanatory value.

\section{Vulnerability factors instigate a negative vicious spiral; protective factors incite a positive upward spiral}

The effort to identify possible vulnerability and protective factors in the context of chronic pain has obvious theoretical gains. But maybe the most important contribution of these types of studies is that it raises awareness among therapist about these factors. The fear-avoidance model can then be used to explain the patient's pain condition and how their vulnerability factors can instigate a vicious downward spiral that results in maladjustment to pain. While their protective factors may incite a positive upward spiral, that promotes a positive adaptation to pain. Curtin and Norris take an interesting step in identifying the relation between ruminative anxiety, mindfulness and components of chronic pain. However, as the authors themselves point out, more scientific scrutiny is required to identify the underlying mechanisms by which these factors exert their protective effects against chronic pain suffering.

\section{Conflict of interest}

None declared by the authors.

\section{References}

[1] Curtin K, Norris D. The relationship between chronic musculoskeletal pain, anxiety and mindfulness: adjustments to the fear-avoidance model of chronic pain. Scand J Pain 2017; 17:156-66.

[2] Vlaeyen JWS, Linton SJ. Fear-avoidance and its consequences in chronic musculoskeltal pain: a state of the art. Pain 2000;85:317-32.

[3] Garland EL, Fredrickson B, Kring AM, Johnson DP, Meyer PS, Penn DL. Upward spirals of positive emotions counter downward spirals of negativity: insights from the broaden-and-build theory and affective neuroscience on the treatment of emotion dysfunctions and deficits in psychopathology. Clin Psychol Rev 2010;30:849-64.

[4] Sturgeon JA, Zautra AJ. Resilience: a new paradigm for adaptation to chronic pain. Curr Pain Headache Rep 2010;14:105-12.

[5] Vlaeyen JW, Crombez G, Linton SJ. The fear-avoidance model of pain. Pain 2016;157:1588-9.

[6] Crombez G, Eccleston C, Van Damme S, Vlaeyen JW, Karoly P. Fear-avoidance model of chronic pain: the next generation. Clin J Pain 2012;28:475-83.

[7] Finan PH, Garland EL. The role of positive affect in pain and its treatment. Clin J Pain 2015;31:177-87.

[8] Ostelo RW, Vlaeyen JW. Attitudes and beliefs of health care providers: extending the fear-avoidance model. Pain 2008;135:3-4.

[9] Jennings EM, Okine BN, Roche M, Finn DP. Stress-induced hyperalgesia. Prog Neurobiol 2014:121:1-18. 